\title{
Bridging Across Language Divide for Growth and Peaceful Coexistence: A Panacea for Economic Recession in a Multilingual Nigeria
}

\author{
Timothy Kolade Akinwamide \\ Arts and Language Education Department, Ekiti State University, Ado Ekiti, Nigeria. \\ Email: wamide.tk@gmail.com
}

\begin{abstract}
Language - a human phenomenon, which is the basic means of communication among the world citizens has generated 'a great divide' as a result of non understanding of terms, patters and words in different languages of the world. Our cultural heritages are expressed basically in our languages. This aptly explains the balkanizations of peoples along political, religious and economics interests. The aftermath of this divide is often seen in internecine and socio-economic doldrum with the attendant effect of poverty. This paper is advocating for bridging across our language divides - minority and majority languages - to connect us to the inherent dividends in a multilingual society. It is believed that no society stands in isolation in the bid to achieve overall success for her citizens. The colonial masters did not understand our languages yet they came, explored, extracted and made exploits from the flora and fauna in the terrain of Africa continent. There are lot of economic benefits that are available in the vast land of Africa which language divides have buried beyond our reach.
\end{abstract}

Keyword: multilingual; communication; interaction; economy; languages

\section{Introduction}

There has been a disquieting issue of concern that has been downplayed or forgotten anytime we are talking about factors contributing to the slow development of our economy as a multilingual nation. Other factors like bad leadership, corruption, political instability and the likes are constantly mentioned but language divide is often not considered a factor to be reckoned with. It is like developmental issue in our landscape is language neutral.The moment the three major languages viz: Hausa, Ibo and Yoruba are mentioned and English Language which is spoken by the few elites, it is assumed all is settled. The pertinent questions to ask are that: are we saying the teaming population in the rural and minority languages areas where we have the labour market have nothing to contribute to our economy? Are the natural wealth in our landmass confined to the environment of the few majority languages areas alone?

Kaplan 2012 says language is how individuals communicate to acquire knowledge, and work with others. It is how societies pass on culture and institutions, import new ideas and technology, and forge links among members. It can unite as well as divide, act as an instrument of empowerment as well as a barrier to advancement, and influence how societies evolve and develop. This aptly explains the divide in multilingual nations like Nigeria, DR Congo, Uganda, Ghana and others; where language divide is not helping the economy to grow and peaceful coexistence has been elusive. Akinwamide 2015 says, it is in this perspective that political upheaval is seen for example in Nigeria insomuch that a thorough assessment of 
the political affliation of the country can be traced to language sentiments. Every region tilts politically towards a domiciled political party in that region.

Hubbard 2007 says at the root of every confusion and restlessness is the misunderstood language. It is the greatest barrier to study, peaceful coexistence and bilateral relations. In a multilingual country like Nigeria, where there is one foreign language as an official language, such policy inherently cuts off the majority non-elite. Kaplan says further that by using an official-European Language as the basis of education and governance, they entrench elites in power, and reduce the possibility of the general population to acquire knowledge and updated information.

One may begin to wonder why after colonialism has ended in Africa, foreign languages like English, French, Arabic and Portuguese still matter much more than African languages in most countries even when they are not well spoken by the teeming rural population and urban underclass, which constitute the majority. The disadvantages the poor face directly contribute to the apparent inequities and class separations that plague such countries.Onadipe-Shalom (2015) opines that the language policy that singles out only 3 languages for special attention is absolutely unjustifiable to minority languages because it denies the tenet of equal opportunities for all languages.

\section{The Pitfalls from Language Divides}

Language affects the thought and behaviour of human beings. The attitude of a person speaking more than one language is not the same as others who speak just one language. The first person can comment on issues from different viewpoints. He/she can see and evaluate the events in a better and broader perspective as against the narrow view through one language. As knowledge gives insight, security, peace and confidence to human beings, ignorance causes suspicion, repulse and mistrust. Ability to converse in other people language means entering a world of interactive thinking, observing differently, accepting different life-styles, harmonizing and clarifying the obscurities which are the root cause of prejudice and prolonged conflicts. The following are some of the inherent pitfalls of language divides bedeviling Nigeria multilingual polity.

Not quite long, the Junior Secondary Segment of the 6:3:3:4 educational programme in Nigeria suffered a major blow in the area of language, right from inception. There were lot of machineries imported from Russia and deposited into Technical Workshops of many schools. These machineries till date were haphazardly installed, some were not installed while Nigerian Teachers could not test run or operate the machineries all because no one could read the manuals; hence they rotted away in the various schools. At this juncture, the J S S 3 which was planned to cater for those who would pursue Trade work and Technical professions suffered a major set-back; till today the graduands of this system of education are left with the academic option.

Language Divide in Political Party Formation: Akinwamide (2016) says, it is evident throughout Africa and beyond that political parties have large membership from the language area where they are domiciled. The history of political party formation in Nigeria can be traced to reflect this divide. The first political parties were formed before independence in 1959 viz; National Council of Nigeria and the Cameroons NCNC led by Nnamidi Azikwe, Northern People Congress NPC, led by Ahamadu Bello and Action Group led by Obafemi Awolowo. All these political parties were populated by people speaking the language in the 
home base of the political parties, hence, suspicion and schism were the other of the days. There has been no significant difference in the polity even as at now. All that this language divide is breeding are mistrust, insecurity, nepotism and schism which are quite unfavourable for economic development.

Language Divide in Religious Affliation: the northern part of the country speak mainly Hausa and Arabic and they are muslim. The Arab adventurers that invaded the northern part spoke Arabic while the southern part majorly speak Yoruba and Igbo with English and they are majorly Christians. This came as a result of the Missionaries that came with English Language. Cameroon also is polarised between French and English Languages. The societal segregation in religion is highly noticeable when Northern and Southern muslims come together, the muslims from the north do not accept the leadership of those from the south -the non Hausa speakers.

Language Divide in Societal Interaction: on June 6, 2017, some 16 northern youth groups gave Igbos residing in the northern Nigeria 3months ultimatum to vacate the northern Nigeria states. The President who has been away on sick leave spoke to one of his allies in Hausa Language which was greeted with a loud outcry from the non-Hausa speakers. Igbo are the ones at the economic wheel of Nigeria and because of the ultimatum, some have been packing in panic and for sure this is having a negative impact on the Nigeria economy.

Language Divide in Appointment Disposition: appointment into governmental and nongovernmental services in Nigeria is not by merit but contingent upon where one hails from or the language one speaks. The implication of this is that, the right people are not employed and the best in organisational inputs and outpot are elusive.This has emboldened criminality and many anti-social behaviours. It is often a common issue to see convicts given a heroic welcome by his kilths and kin after serving the terms of imprisonment.

Language Divide in Admission into Institutions: just like the appointment issue, admission into higher institutions are also based more often on immediate vincinity often tagged 'Catchment Areas'. Where is the catchment areas if not the people of a given language areas. It is a common occurence in Nigeria institutions to hear about offer of Scholarship to students from a particular language area. Bursary awards are even publicised on national dailies for indegens of a particular language area. The seed of the division is sown into the mind of the young ones right from the higher insstitutions.

Language Divide in News Circulation: Newspapers in local languages tend to stick to their region or language of immediate communities because of acceptability. 'Alaraoye' newspaper which is written in Yoruba language is only in circulation in the south western part of the country and that is the case with other indigenous language that have orthography, unlike other newspapers written in English language which tend to have a wider spread through the length and breadth of the whole country.

Language Divide in Music Production: The entertainment industry has developed along ethnic/ language line,the popular trans Africa cable network DSTV has also helped in sustaining the language divide across the entertainment industry as local music and drama are aired on each specific language channel,this divide has earned DSTV as the largest cable network viewed by millions of Nigeria.The acceptance of the cable network is grounded on the fact that each person can relate to his or her language and a level playing ground is provided for any artist to produce and perform their act knowing fully well their target audience will be reached. 
Language Divide in National Policy Interpretation (NYSC): The act that promulgated the NYSC scheme had as it is main objective of fostering unity across the nation in order to achieve this, youths are posted to other states other than their state of origin in order to aid cultural and language assimilation. However due to mistrust and insecurity in some parts of the country and inability to communicate in local dialect of the host communities the laudable policy has been redefined. In most cases, the corp memberslook for who can influence their postingswhile over population of camps are witnessed in most cosmopolitan cities/states in the country as youth corp members do not feel safe in states where they feel there is a language barrier.

Language Divide in Restructural Agitation: currently, the three major language speaking areas are clamouring for restructuring. This is not unconnected with the offshoot of language divide. The Hausa speaking northern people under the auspices of AREWA wants to stand aloof of others. In the Southwest, OPC (Oduduwa People Congress) wants their own nation while 'Ohanneze' Ndigbo standing for Igbo speaking nation.

\section{The Implications of Language Divide}

The aftermath of this scenario is quite unwholesome and worrisome on a nation that is quite unequivocally in her yearning and aspirations for the citizens development. It is a common occurence in the Nigeria state to experience:

* Insecurity/suspicion

* Political upheaval

* Absence of interactions

* Inability to locate and access raw materials produced in certain parts of the country

* Schism and tribalism which often result in internecine

* Inability to locate and localise good market for local products

In the National Objectives of Nigeria, it is stated that, the nation wants

$>$ a free and democratic society

$>$ a just and egalitarian society

$>$ a united, strong and self-reliant nation

$>$ a great and dynamic economy and

$>$ a land full of bright opportunities for all citizens (National

Policy on education, 2007)

These lofty objectives become elusive when juxtaposed with the aftermath of the identified language divide.

\section{Building A Bridge Across Our Language Divide}

For any multilingual nation to come out of the type of quagmire that is being experienced in Nigeria, it is necessary for all stakeholders to shelve the swords of schism and nepotism and harness the inherent benefits available in the land. The following are among the steps that could be taken for peaceful coexistence where a strong economy will thrive for all;

- recognition and development of the indigenous languages

- development of e-materials on the minority languages

- development of modern literacies links for news circulation in every language 
- compliance with the national philosophy on language learning

- enhancing the NYSC scheme to achieve the unity objective

- enhancing the movie industryto teach cross-cultural education

- promotion of tourism for healthy interactions

- promotion of positive values about every other culture in schools and all societal fora

- building of the music industry to exhibit the values of others and

- developing literature in minority languages.

\section{Conclusion}

Necessity is the mother of invention, therefore our present needs as a nation should lead us to harness our resources and turn language divide to life dividends. The movie industry- Nollywood according to May 2009 UN report states that 56 percent of Nollywood films are made in local languages while English remains a prominent language, accounting for 44 percent, which may contribute to Nigeria's success in exporting its films. Ugochukwu (2013) says even though one can rightly argue that film productions in Nigerian languages, restricted by the language barrier, are primarily targeting local audiences and their diaspora. One cannot deny the fact that a good number of Nigerians are keen to access films in other Nigerian languages - You get people in Calabar watching Igbo stories and Yorubas' learning about Oron warriors.People now speak Igbo words and pidgin English in far-off places like South Africa as a result of this. The youths can be exposed to the modes of living of the people in different parts of the country with a view to removing prejudices eliminating ignorance and confirming at first hand the many similarities among Nigerians of all ethnic groups (Ibaba, 2009). Therefore, it is only where there is peaceful atmosphere and healthy rapport that economy can thrive.

\section{References}

Akinwamide T.K. 2013 Literacy in the $21^{\text {st }}$ Century: Turning Language

Divides to Life Dividends on the Concomitant Paradigms of Print and Internet.In the Journal of the Reading Association of Nigeria. 14(1),185-189 AtlanticsAssociated Publishers, Lagos.

Akinwamide T.K. (2016) The Upshot of the Misunderstood Language

Concept on the Achievement of Secondary School Students in Mathematics - The gateway to Science and Technology. In theJournal of Science Education, Faculty of Education, Ado Ekiti.

Hubbard R. Prog L. (2005) Progressive Teaching Tools. Effective

Education Publishing 11755 Riverview Drive.St. Louis/Missouri 63138 USA.

Hubbard R. L. (2007) Fundamentals of Study Technology.

Effective Education Publishing 11755 Riverview Drive. St. Louis,Missouri 63138 USA

Ibaba, I. S. (2009) Education and National Integration in Nigeria. Journal of Research in National Development Vol. 7 No. 2. Retrived online July 4, 2017. www.transcampus.org

Kaplan (2012)Cultural Thought Patterns in International Education Language

Learning. USA. 
Budapest International Research and Critics Institute-Journal (BIRCI-Journal)

Volume I, No 3, October 2018, Page: 01-06 e-ISSN: 2615-3076(Online), p-ISSN: 2615-1715(Print)

www.birci-journal.com

emails; birci.journal@gmail.com

birci.journal.org@gmail.com

Onadipe-Shalom, T. (2015) Globalization and the Survival of Minority Languages: The Case of the Ogu Language. Journal of the Linguistic Association of Nigeria. Vol. 18 No. 1 pp 95-109.

Ugochukwu, F. (2013) Nollywood across Languages. Issues in Dubbing and Subtitling. http://www.immi.se. Retrieved July 4, 2017. 